\title{
A COMMUNITY TEXT PATTERN IN THE EUROPEAN COMMISSION PRESS RELEASE? A GENERIC AND GENETIC VIEW
}

\author{
Maria Lindholm
}

\begin{abstract}
This contribution is concerned with press releases from the European Commission and national ministries. Political press releases may serve other purposes than those issued by business organisations, and they are also a fairly unexplored field in press release research, which this study sets out to remedy. The linguistic dimension of EU communication is also a neglected field of study, and this paper is aimed at introducing the linguistic dimension of the European Commission communication as a field of study worthy of closer examination.

Within a genre-based analytical framework, the present paper aims at examining to what extent we can identify a unique community text pattern in European Commission press releases. I propose a macrostructural text analysis in which I compare a number of press releases issued by the European Commission with national equivalents from French and Swedish ministries. In particular, I will focus on three recurrent and characteristic text features of the European Commission press release, viz. the introduction, the quotation and the intertextual references. It is shown that the way they are designed in the European Commission press release is quite special and that this can be explained with reference to the communicative situation of the European Commission. In doing so, I will be drawing on ethnographic data that I gathered from fieldwork at the European Commission.

It will be suggested that the results from this study can be extrapolated to the study of press releases in general. That is, press release research may benefit from the genre-based methodological approach chosen here, since, indeed, the press release is a situated practice whose understanding depends on a comprehensive study of the communicative situations it functions within.
\end{abstract}

Keywords: Press releases; Text pattern; Genre analysis; Ethnography; EU; European Commission; Intertextuality.

\section{Introduction}

In contrast to the other contributions in this volume, this paper deals with political press releases. During the last couple of years the European Union has shown an increased awareness of the importance of efficient communication as well as a more transparent legislation to get closer to its citizens. Therefore, it has become even more relevant to examine more thoroughly how the EU seeks to position itself in its proper texts (cf. Amossy 1999). This will be done by examining one of all the EU text genres associated with its communication: The European Commission press release ${ }^{1}$.

\footnotetext{
${ }^{1}$ However, communication issues are not new in the EU context. See for example the White paper on a European Communication Policy (European Commission 2006), the Action plan to improve communicating Europe by the Commission (European Commission 2005b), the communication $A$ new
} 
The European Commission - and in a more general sense the European Union - is a fairly recent text producer, compared with the national administrations of its member states. However, this does not imply that the EU is a modest text producer. On the contrary, the EU produces an ever increasing number of texts, ranging from legal texts binding for the member states to information to the public ${ }^{2}$. With its linguistic regime of considering all the official languages of the member states as official languages of the union, the EU provides a unique linguistic setting: Since January 2007 the EU is dealing with 23 official languages, whereas, as a comparison, the United Nations works with six official languages.

The multilingual character of the EU, like that of other international organisations, implies that numerous writers work in a foreign language. Considering the fact that we seem to construct our texts according to text patterns learned when acquiring our native tongue, even when we write in a foreign language (cf. Gunnarsson 1996; Vergaro 2005), the text production of an international body such as the European Commission becomes an interesting sphere of investigation. If the language use of other international organisations has been studied to some extent (cf. Duchêne 2004, 2006; Maingueneau 2002), an integrated analysis of linguistic and communicative aspects is lacking in the studies of the European Union. In fact, it is "remarkable that there has been so little empirical research on EU institutional language use until now" (Loos 2004: 6). A study of the language use of the EU is called for not only from a need to develop a fuller understanding of the linguistic practices of the European Union, but also because once outlined it can be put in relation to research on text production in other international organisations and companies in general, and press release writing in particular.

The present paper aims at examining if we can identify a unique community text pattern in press releases issued by the European Commission. As part of a wider research project (Lindholm 2007), it draws on an analysis of macro-structural text features of European Commission press releases compared with national press releases from French and Swedish ministries. By taking a genre-based approach, my aim is to examine to what extent recurrent and characteristic features of the European Commission (henceforth Commission) press releases can be explained by insight into the overall communicatiive situation of the Commission. Also, the study seeks to discuss what the linguistic features examined can reveal about the position of the Commission within the broader institutional landscape of the EU. The text analysis is combined with fieldwork at the Commission and it will be argued that the ethnographic information obtained to provide this "genetic" view of how the press release is drafted is crucial for an understanding of it.

In general terms, the communicative situation of the European Union entails some peculiar features. The EU is not a nation state, nor a federation or an international organisation. It is still difficult to talk about European public opinion, mass media or language for that matter. The Commission has to communicate with its 27 member states, but lacks a common language to do so. In addition, there are no widely spread and common media in the different member states, and the institutional climate is

framework for co-operation on activities concerning the information and communication policy of the European Union (European Commission 2001) and the report Reflection on Information and Communication Policy of the European Community (European Commission 1993).

${ }^{2}$ As an example, the portal site Europa (http://europa.eu) launched in 1995 contains more than one million documents, if all language versions are counted together. 
different in so far as the EU is still a project "under construction" ${ }^{3}$. The relations between the different institutions are not set and treaty modifications may change considerably the political direction of the union. Foret describes the communicative situation as "a lack of a real communication sphere and of a common register shared by the citizens and the power at the European level" (2004: 168). Indeed, the "complexity of the EU as a communicative space” (Schlesinger 2003: i) has gained the interest of a wide range of scholars, although linguists are not prominent among them. It needs to be stressed here that it is not adequate to simply transpose national conditions to the EU level; the specificity of the EU institutional organisation requires a reconsideration of the analytical tools used ${ }^{4}$.

Zooming in on the Commission, the Commission press releases issued are aimed for the Brussels based journalists. They are part of a communicative sequence and are not to be seen as an isolated communicative event. The press releases are issued in direct connection to a daily press conference, the Midday briefing, and they are the result of an interesting text production process, whose collaborative nature has counterparts in national ministries and national and international organisations. However, the Commission press release is supposed to fulfil a communicative end in more than 27 countries, which may seem an ambitious but difficult communicative project, especially since the way of structuring information is culturally determined (cf. Gunnarsson 1996; Vergaro 2005). Also, we do have to add the multilingual character of the EU and the rather specific communicative preconditions of the Commission, as appears from the following quotation:

The Commission is a hybrid institution acting both as the EU's supreme political executive and as its administrative Eurocracy (Lodge 1994: 362).

That is, the Commission is bound by both a political and an implementative function, which complicates further how the institution can and should position itself.

The text features in focus will also be seen in the light of a length restriction imposed on press releases due to lack of translation capacity after the enlargement of the EU with ten new member states in 2004. A legitimate question is whether the changed prerequisites of the genre in some way influence the text pattern, and if the text features remain as characteristic for the press release. Thus, the objectives of the present paper can be pinned down to the following research questions:

1. Do some characteristic text features of the Commission press release make it relevant to talk about a Community text pattern?

2. If so, to what extent are differences conditioned by the requirements of the communicative situation of the Commission, including the text production process?

3. And, finally, just how typical are these text features, i.e. does a requirement to shorten the press releases have any impact on them?

${ }^{3}$ In fact, Jacques Delors once labelled the EU as an "unidentified political object” (Shore and Abélès 2004: 11).

${ }^{4}$ In this respect, see for example Guiraudon (2000), Lequesne and Smith (1997), Schlesinger (1999) and Smith (1999, 2000). 
Naturally, with this research focus, the communicative situation of the Commission is my main interest; the national contexts have not been investigated to the same extent. The comparison between the EU-produced text genre and its national counterparts serves as a starting point, although the discussion centres around the "new" situation occurring when the Commission is communicating with the Brussels based journalists and in extension with the citizens of the union. It has to be stressed that the EU as such is a unique organisation. There is no exact matching between the EU and national institutions, but the Commission, with its Directorates-General covering different policy areas, is in my view best compared to national ministries since the Directorates-General (DGs) are the organisational equivalent of the government ministries in the member states. Besides, the Council of Ministers and the European Parliament are the decisionmaking bodies of the EU, so the Commission is no "government" in that sense.

I will begin this paper by outlining my theoretical and methodological assumptions. After a presentation of my data, three typical features of Commission press releases will be identified. I will try to explain them by referring to the Commission's daily institutional practices. In particular, I will report on the field research that I did at the Commission. Finally, I will return to the typical text features and present a concluding discussion. At first, let me introduce some previous studies of relevance for this paper.

\section{Previous research}

The linguistic situation of the EU has attracted interest from linguists when it comes to the linguistic policy and regime of the EU and the status of the official languages (Balboni 2004; Mamadouh 1999; Marzocchi 2005), translation issues (Koskinen 2000; Schäffner 2001; Sosonis 2005) and the EU jargon (or Eurojargon) (Goffin 1997). This last is often interpreted as a number of strange sounding words "not understandable at all” for most outsiders (Bellier 2002: 105) ${ }^{5}$, and the focus of studies undertaken has been on the lexical level whereas it can easily be assumed that the text production of the EU would affect other linguistic levels as well (see also Berteloot (2002) where the need for further studies is stated).

Interestingly, little attention has been paid to the requirements of the EU's specific communicative situation, in general, and the situated text production process, in particular. Wodak (2000) and Loos (2004) are two exceptions. Loos conducted a case study at the European Parliament to investigate how actors from different countries and political groups and with different mother tongues produce texts together, and Wodak followed the genesis of a policy-paper. Wodak's paper is included in the collective volume European Union Discourses on Un/employment : An interdisciplinary approach to employment policy-making and organizational change (Muntigl, Weiss and Wodak 2000) which takes on a CDA perspective in the study of discursive practices of the EU. However, neither of these focuses on the communicative practices of the EU.

As for the specific communicative situation of the EU, it has been of interest to anthropologists (Abélès 1996) as well as to sociologists and political scientists (Baisnée 2004; Bastin 2005; Dacheux 2004; Foret 2004; Joana and Smith 2002 and Meyer 1999); however none, or very few studies, have focused on the linguistic aspects of

${ }^{5}$ Bellier is an anthropologist who in this paper studies the linguistic regime and identity construction in the context of enlargement. 
communication $^{6}$. Baisnée (2003) and Bastin (2003) have conducted fieldwork within the Brussels press corps, and have provided as such a good base for the present paper. However, it becomes evident that these previous studies either have a linguistic or a communicative focus, whereas this study seeks to integrate them.

\section{A generic perspective on press releases}

The present study takes on a generic approach to press releases and this section presents some of the central assumptions I start from: The routinised, recurrent, intertextual and culturally specific nature of genres.

According to Günthner and Knoblauch, genres are "generated as soon as communicative interactants are faced with recurring problems which are of great relevance to the actors" (1995: 6). Genres can be seen as routinised - albeit dynamic solutions to specific problems which help the participants by providing a "nonproblematic" framing, so that they can concentrate on other tasks (ibid.). In this sense, genres are a response to recurrent situations, which indeed holds true for press releases.

Furthermore, an understanding of the intertextual nature of genres is crucial (Bakhtin 1986). I have indicated that the Commission press release is part of a communicative sequence. The Commission press release is issued in connection to the daily press conference of the Commission, the Midday briefing. In fact, the press releases are often formulated with respect to possible questions from the journalists gathered in the press room of the Commission. Also, a central feature of the Midday briefing is the Midday Express. The Midday Express is the Commission's summary of the key announcements of the day and is made up of the introductions of the press releases issued, as well as references to speeches and other material issued. In addition, the press release is only one of several texts on the same issue. Reports, underlying legislation and additional information material to go with the press release are other texts which are part of the same textual universe. Many of them are also explicitly drawn upon in the press releases and when the notion of intertextuality is used in this paper, it should be understood as the literal presence of one text in another text, often by a reference to the document name, more rarely by a quotation from the actual text ${ }^{7}$. On the other hand, the analysis of the communicative situation of the Commission will open up a complex intertextual and interdiscursive universe making way for further studies.

Since the genre framework proposed here sees genres as a socially embedded and situated practice, the cultural specificity of genres is also a salient feature. Studies have shown that people organise discourse differently and that text patterns vary according to cultural contexts (Gunnarsson 1996; Günthner and Knoblauch 1995; Mauranen 1993; Vergaro 2005). This underlies my interest in seeing if a particular community text pattern has developed within the Commission.

${ }^{6}$ A paper by Diez (1999) deserves to be mentioned for emphasizing the role of language in European integration, although it is not devoted to the study of EU communicative practices either.

${ }^{7}$ For instance, Genette reserves the term intertextuality for "the literal presence (more or less literal, whether integral or not) of one text within another” (1992: 81f), where a quotation is the most obvious example although the intertextuality does not stop there. A parallel labelling is the manifest intertextuality of Fairclough (1992). 
A source of inspiration of particular relevance for this paper is the Günthner and Knoblauch approach for analysing communicative genres (1995) ${ }^{8}$. They propose to analyse the structural elements of a communicative genre by its level of internal structure ("linguistic signs of communicative action"), the situative level ("those elements which are part of the ongoing interaction”) and the level of external structure ("the 'situated' elements referring to the institutional structure of a society") (ibid.: 8). The genre analysis undertaken here provides this multi-level approach, since structural features of the texts will be related to the situation framing their issuing and also, in a wider sense, to the communicative situation and the institutional position of the Commission.

Finally, if formal aspects are not defining a genre, it has been argued that an overarching communicative purpose is a defining feature of a genre. This view has been somewhat challenged by Askehave (1999) and Askehave and Swales (2001) who argue that a communicative purpose is too simple a solution since a given text generally has more than one purpose, and that the purposes of a text stand out only after careful analysis. As for press releases, it is generally assumed that the primary function of a press release is to inform. However, I find it interesting to draw a parallel to Tardy's (2003: 7) description of grant proposals as a text genre in which every textual feature must be persuasive without appearing to be so $^{9}$. To a large extent, this is applicable to press releases as well: They must persuade the reader that the message is an adequate piece of news and not a concealed promotional effort. "We can't be too propagandistic but need to spin a bit, to show why it's necessary that we do something" a spokesperson of the Commission told me in 2005. The Commission constantly needs to indicate the necessity for an action to be undertaken at the EU level:

Not only should the press release give details of the Commission's latest initiative, report or event, but it should help support a wider strategic message - about the 'added value' of the European Union. Each press release should demonstrate how the EU delivers benefits to citizens which only EU action could achieve (European Commission 2003: 1).

In fact, the "persuasive" aim goes hand in hand with a legitimising need for the Commission, which will be evident from the discussion later on. Accordingly, a text often has several purposes and one of the most important tasks for the analyst is to unveil the hidden purposes, which makes it necessary to look at the communicative situation in which the text functions ${ }^{10}$.

8 Although elaborated with oral interaction in mind, the present approach is, I would argue, applicable to written communication also. Besides, at the outset, theories on communicative genres were neutral when it comes to mode (Luckmann 1989: 165).

9 See also Connor and Mauranen (1999) and Vergaro (2005) for a similar discussion on grant proposals and "For Your Information" letters respectively.

${ }^{10}$ Lassen (2006) recently argued that the press release is not a genre but a channel "used as a vehicle to carry a variety of rhetorical objectives, and hence a variety of genres” (ibid.: 506). Her main argument is that genre labels "are based on textual form more than on communicative function, content and rhetorical objectives" (ibid.: 511). In this study, however, it is considered that more than one communicative purpose - or rhetorical objective as Lassen has it - should not prevent us from calling the press release a genre, especially since formal criteria have not been the vital point in assigning the press release its genre label. 


\section{Method and data}

I have chosen to combine text analysis and ethnography in order to be able to investigate press releases from a product as well as a process perspective. First, an analysis of the texts revealed systematic differences in the textual composition, i.e. the macro-structure, of the Commission press releases compared with those of the national ministries. This seems to indicate that the Commission press releases are based on the kind of distinct text pattern that we are looking for.

Second, the text-based analysis was combined with fieldwork at the Commission, on two occasions and at two different Directorates-General, DG Translation and DG Communication. Ethnographic methods such as participant observation, interviews and informal discussions (often with a subsequent e-mail exchange) were used in order to seek explanations for the differences I perceived and the decisions guiding the issuing of press releases.

The core data consists of press releases issued by the Commission and by French and Swedish ministries, from 2001 and 2002. I have worked on a corpus consisting of 100 press releases, distributed in four groups of 25 texts (i.e. the same 25 Commission press releases in French and Swedish and 25 press releases from French ministries and 25 from Swedish ministries). When choosing the press releases, I have avoided focusing on one theme since I considered it important for this kind of initial research to have a comparatively wide sample of texts with different themes, in order to get a more general picture of the press releases as a group. However, the national press releases are not related to the EU press releases in the sense that they would be a response on a national level to an initiative undertaken on the EU level. Besides, the comparison with the national press releases was an intralinguistic one, i.e. the French Commission press releases have been compared with the national French press releases and the same goes for the Swedish press releases.

The corpus has been completed with 101 Commission press releases in French issued in February 2005, i.e. from the time of my research visit to DG Communication, in order to examine whether a length restriction imposed on the press releases in May 2004 had any effects on the structural features of the press releases (see section 7 for further discussion).

\section{The Commission press release text pattern - first round of analysis}

In this section, I will take a look at what the comparison between the Commission press releases and the press releases from national ministries revealed. It will be argued that it is possible to talk about a Commission text pattern in the press releases, in that way I was able to identify systematic differences which distinguish the Commission press releases from the national ones.

However, let us begin with the similarities. First of all, all groups are characterized by a need to inform journalists (and the public). As for the homogeneity of each text group, the Commission as well as the Swedish press releases have an identical format and macro-structure. The macro-structure of the French press releases in my study varies according to the ministry. Other common elements include such typical press release features as the dating and third person self-reference, the latter being an aspect of what Jacobs labels preformulation. By preformulation is meant "those specific 
language features that make press releases look like news reports" (Jacobs 1999: xiii). For example, if the press release is written in third-person already, it facilitates the work of the journalist: Instead of rewriting (or not using) the press release, he or she can simply copy it.

A very common opening sentence of the press releases, in line with the idea of preformulation, thus consists of introducing the Commission in the third person, using its proper name, and stating up front an action undertaken:

(1) The European Commission has decided to propose to the French Government to remove the unlimited State guarantee that EdF enjoys under the so-called EPIC status and to charge a premium for not yet redeemed bonds issued by EdF with an explicit State guarantee (IP/02/1485) ${ }^{11}$.

or:

(2) The European Commission has outlined a new Interactive Policy Making initiative to improve governance by using the Internet for collecting and analysing reactions in the marketplace for use in the European Union's policymaking process (IP/01/519).

The same pattern of third person self-reference is perceivable within the national groups:

(3) Regeringen har i dag beslutat inrätta ett råd för romska frågor inom Regeringskansliet ${ }^{12}$.

'Today the Government decided to create a council for Romani issues within the Government Offices of Sweden.'

(4) Roselyne Bachelot-Narquin, Ministre de l'Ecologie et du Développement Durable, conduit la délégation française à la Huitième Conférence des Parties à la Convention Climat à New Delhi ${ }^{13}$.

'Roselyne Bachelot-Narquin, Minister for the Environment and Sustainable Development, leads the French delegation at the Eighth session of the Conference of the Parties to the UN Framework Convention on Climate Change in New Delhi.'

Interestingly, in my corpus, the Commission and the Swedish ministries seem to favour an institutional voice, not only in the third person, but with an emphasis on the collective instead of the individual action of the commissioner or the minister. The European Commission or the Swedish government are explicit senders of the press releases, whereas when it comes to the French ministries, the action is centred on the

11 Throughout the paper, the English language version of Commission press releases is used whenever examples are given. The translation matters arising will not be touched upon here. Commission press releases can be found in the Rapid date base of the Commission (http://europa.eu/rapid/searchAction.do).

12 http://www.regeringen.se/sb/d/119/a/6930, retrieved 28 November 2002.

13 http://www.environnement.gouv.fr/actua/com2002/octobre/30-COP8-New-Delhi.htm, retrieved 8 November 2002. 
minister. However, the vast majority of the press releases analyzed were "populated" by an individual person, either a minister or a commissioner.

It can easily be argued that a reference to the Commission as a sender is not necessarily clear-cut, even less so than a reference to a national ministry. Do we speak of the Collège (i.e. the group of commissioners appointed by the member states but representing the common interest of the EU), the Commission as an institution, the Directorate-General which has done the footwork behind a given proposal, or the some 24000 officials working for the Commission? Or does the Commission act on behalf of the whole EU?

Having briefly discussed similarities in the press releases, I will now focus on the differences. To begin with, a difference in length was easily perceived. The average Commission press release consists of 1060 words in the French version and 875 in the Swedish version. In contrast, the average French press release consisted of 286 words, and the average Swedish one of 285.

Subtitles as well as bullet point lists are more frequent in the Commission press releases. This may be due to the length of the texts. In addition, an internal style guide for how to write press releases states that these structuring elements facilitate the reading (European Commission 2003). Internet references to further information were more frequent in the Commission press release, although the Swedish texts always refer to the general ministry web site.

The structural features I will concentrate on are the introduction, the quotation and the intertextual references. They are all more frequent in the Commission texts; for instance, every single Commission press release in my corpus has an introduction, whereas this is a feature of only two of the Swedish press releases and none of the French.

As for the introduction the length varies from one to 14 sentences, but all Commission press releases have one. According to an internal style guide for press releases the introduction "should be relatively short", "[p]ut the latest news into the context of our overall political aims", and "be able to stand alone as a summary of the key points” (European Commission 2003: 2f). Example 5 shows an introduction (always typed in bold italics). I have italicized those parts which illustrate the "added value” of EU actions in line with the internal style guide.

The European Commission today presented its new proposal for a Directive laying down common rules for takeover bids. The proposal sets out to offer European firms greater legal certainty for cross-border takeover bids in the interests of all concerned, including their employees, and to protect minority shareholders where control of a company changes hands. To provide a framework for such corporate restructuring, which involves the laws and the authorities of more than one Member State, action at Union level is the only way to enable progress. That is why, although the previous proposal was rejected by the European Parliament in July 2001, the Commission has remained convinced of the need for an EU Directive on takeover bids and has spared no effort in order to come forward as soon as possible with a new proposal that is likely to meet with the approval of the Council and Parliament (IP/02/1402, my emphasis). 
Typically, this introduction is followed by a quotation of the commissioner in charge of the dossier (in $80 \%$ of the Commission press releases in French ${ }^{14}$ ). The introduction in (5) is followed by this quotation:

\begin{abstract}
Internal Market Commissioner Frits Bolkestein said: "The aim of this proposal is to enable takeover bids to be made in the EU under the best possible conditions for all those concerned. This Directive has always been an essential step towards the objective of fully integrating European capital markets by 2005; it is a key element in our drive to make Europe the most competitive economy in the world by 2010. The new proposal provides concrete responses to the concerns raised by the European Parliament when it rejected the previous proposal last year. I am firmly convinced that this proposal now has every chance of being swiftly adopted by the Council and Parliament. It is a balanced and reasonable text which steers clear of the pitfalls of extreme positions that could have consigned us to Dante's Inferno with no exit. It is the fruit of wide-ranging consultations with European experts and all interested parties. We must now move forward and I hope I can count on all those involved in the decision-making process to make rapid headway" (IP/02/1402) ${ }^{15}$.
\end{abstract}

When referring to the more frequent presence of quotations in the Commission press release, I have in view the more systematic presence of quotations. In fact, with a quotation in only 3 out of 25 (12\%) press releases, the national French press releases were the only ones of the varieties examined to lack a high frequency of quotations. As for the national Swedish press releases, 15 (60\%) contained quotations. The latter were in the form of short comments from the relevant minister; without a distinguishable pattern throughout. In fact, one Swedish press release was even completely composed of quotations distributed over three short paragraphs.

The last feature that will be related to the production process and the communication situation is the higher frequency of intertextuality in the Commission press release. The national press releases have relatively few explicit references to other documents: 4 of the French press releases (16\%) and 5 of the Swedish national texts (20\%). The corresponding number for the Commission press releases is 14 out of 25 for each group (56\%). An example from the last group is found in the second sentence of the following introduction, where a communication is explicitly drawn upon by quoting its name:

Philippe Busquin, the European Research Commissioner today put forward suggestions for promoting the European Research Area initiative. The communication entitled "Providing new momentum for the European Research Area" suggests that the mechanisms for coordinating national research policies should be strengthened and made more efficient. [...] Launched at the Lisbon European Council in March 2000, the European Research Area initiative has become the reference framework for research policy in Europe. Its objective is both to create a genuine "internal market" in research and knowledge, and improve the coordination of national research activities and policies (IP/02/1488, my emphasis).

The explicit reference to other texts is a fairly straightforward indicator of how the Commission positions itself into a universe of texts and discourses ${ }^{16}$. For instance, the

${ }^{14} 64 \%$ of the Commission press releases in Swedish contained a quotation, while four quotations in the originals were transformed into indirect speech during the translation process.

${ }^{15}$ It has to be emphasized though that this is a comparatively long quotation.

16 This analysis could be further developed by including other intertextual and interdiscursive elements, for instance those linguistic features which indicate a blending of perspectives and sources, but that is beyond the scope of this paper. 
quotation above illustrates nicely how the communication is part of the "European Research Area initiative", which was launched at the "Lisbon European Council". Altogether, the fact that the Commission constantly seeks to show how its actions are part of a wider frame is, in my view, an indicator of a different communicative situation than that of the national ministries.

To sum up, I have been able to point at similarities between the text groups examined, but I have also identified differences between the national and the Commission press releases. The three features of the Commission press release focused on will now be related to the communicative situation and the production process. For this purpose, the next section will provide the necessary background information before returning to the three features examined for a second round of analysis.

\section{Information from the field}

This section will provide a genetic view of a typical press release, i.e. an understanding of the production of a press release. As a starting point, however, the communicative situation in which the press releases unfold is presented in greater detail. This includes a presentation of the Spokesperson's service and the Midday briefing, in connection with which the press release is issued. The subsequent section - the second round of analysis - will then relate the text features identified with information from the field. This is where the Günthner and Knoblauch approach (1995) comes in as very useful. From the level of the internal structure touched upon above, the Midday briefing and the events surrounding the issuing and the production of the press release correspond, in my usage, to the situative level, whereas I consider the overall communicative situation as part of the level of external structure.

\subsection{The communicative situation of the Commission}

The DG Communication is responsible for communicative and information issues at the Commission. Since I am interested in the DG's media directed communication, I will narrow the focus of our discussion to the Spokesperson's service. This consists of the spokesperson of the Commission, two deputy spokespersons, six spokespersons attached to the Coordination and planning unit, and 27 individual spokespersons who specialise in specific policy areas. They all report directly to the Commission spokesman. However, unofficially, the commissioners and the spokespersons may consider the latter group to be working for a particular commissioner (responsible for the policy area in question) (Joana and Smith 2002: 197).

The different spokespersons are the link between the Commission and the journalists. They are also the link between a given Directorate-General and the cabinet of the commissioner responsible for that particular policy area (see Figure 1 below for an illustration). The spokespersons are supposed to be the communication experts of this triad, and have the final word about issuing press releases, although there may be substantial pressure from the commissioner's cabinet, which wants to promote its commissioner, or from the DG, which wants to publicise an issue that they have worked 
on for a long time. In fact, even the Commission is aware of its "overcommunication”" They know that they are issuing too many press releases. In 2007, for instance, the Commission issued 1987 press releases. Even if the internal guidelines emphasise that a press release "should ONLY be issued if there is a story worth reporting" (European Commission 2003: 1), the pressure is often high on the spokespersons to issue press releases which, in fact, may be of no great interest to the outside world ${ }^{18}$.

The Commission press releases are aimed at the Brussels based journalists, the largest press corps in the world with some 1000 accredited journalists. These journalists are supposed to be experts on European issues. The European citizens are of course the intended receivers, through the reporting of the journalists. The press release, in this respect, has to fulfil several communicative ends and this is what Jacobs considers one of the central characteristics of press releases: "press releases are meant for different audiences and, naturally, they are also supposed to do different things to them" (1999: 22f; on this issue see also Maingueneau 2002: 125f). The fact that press releases are also aimed at the public is made explicit in internal guidelines of the Commission on press release writing ${ }^{19}$.

The daily Midday briefing is a true institution and needs some further presentation. As a daily gathering open to the accredited journalists, the Midday briefing serves as a natural meeting point for the journalists, especially since the other institutions do not provide the institutional framing for such a routinised gathering. Accordingly, some journalists insist that the prime value of the press conference is to meet other journalists, i.e. the social factor is more important than the information provided by the Commission (Baisnée 2000). Baisnée argues that these journalists may be the only European public to date, in the sense that they cover EU policies from their national horizons and may have poor knowledge about the implications of a decision on the other member states. On the other hand, by participating in the Midday briefing the journalists can, from the questions asked by their international colleagues, see what the national concerns of the other member states are, and, in doing so, they can question their own national situations. That way, the Commission gets an opportunity to anticipate the reception of measures proposed, since what is at stake in one member state is not necessarily at stake in another (ibid.). On the other hand, the daily briefing cannot be reduced to the purely social factor, since it also provides seemingly uninteresting facts that may end up as an article two weeks later, or "things that you need to know" in order to be up to date (Bastin 2003: 284). In this respect, the journalists are an active part of the news production at the Commission and the Commission has for a long time managed to keep this "channel” open through a kind of phatic communication.

When looking at the Commission press releases, it is important to keep in mind that they are issued in direct connection to this briefing - they are not seen as isolated communicative events but as texts which are immediately followed by press conferences (although far from all press releases are commented on). For instance, the Commission has conducted no study of the reactions to the press releases among the

17 "Surcommunication" in French, a term evoked by an official at the DG Communication during an interview in March 2005.

${ }^{18}$ Interviews at the Commission in February and March 2005, and e-mail exchange in 2003.

${ }^{19}$ Although the internal style guide is, surprisingly, not particularly consulted, it is a useful tool in as much as it displays how the press releases are conceptualised at the Commission, i.e. how they "should" be written and what purposes they "should" accomplish. 
accredited journalists since it is argued that they cannot be detached from the oral and material events surrounding them, i.e. the press conference and additional material, like reports and statistics ${ }^{20}$.

\subsection{Genesis of a typical Commission press release}

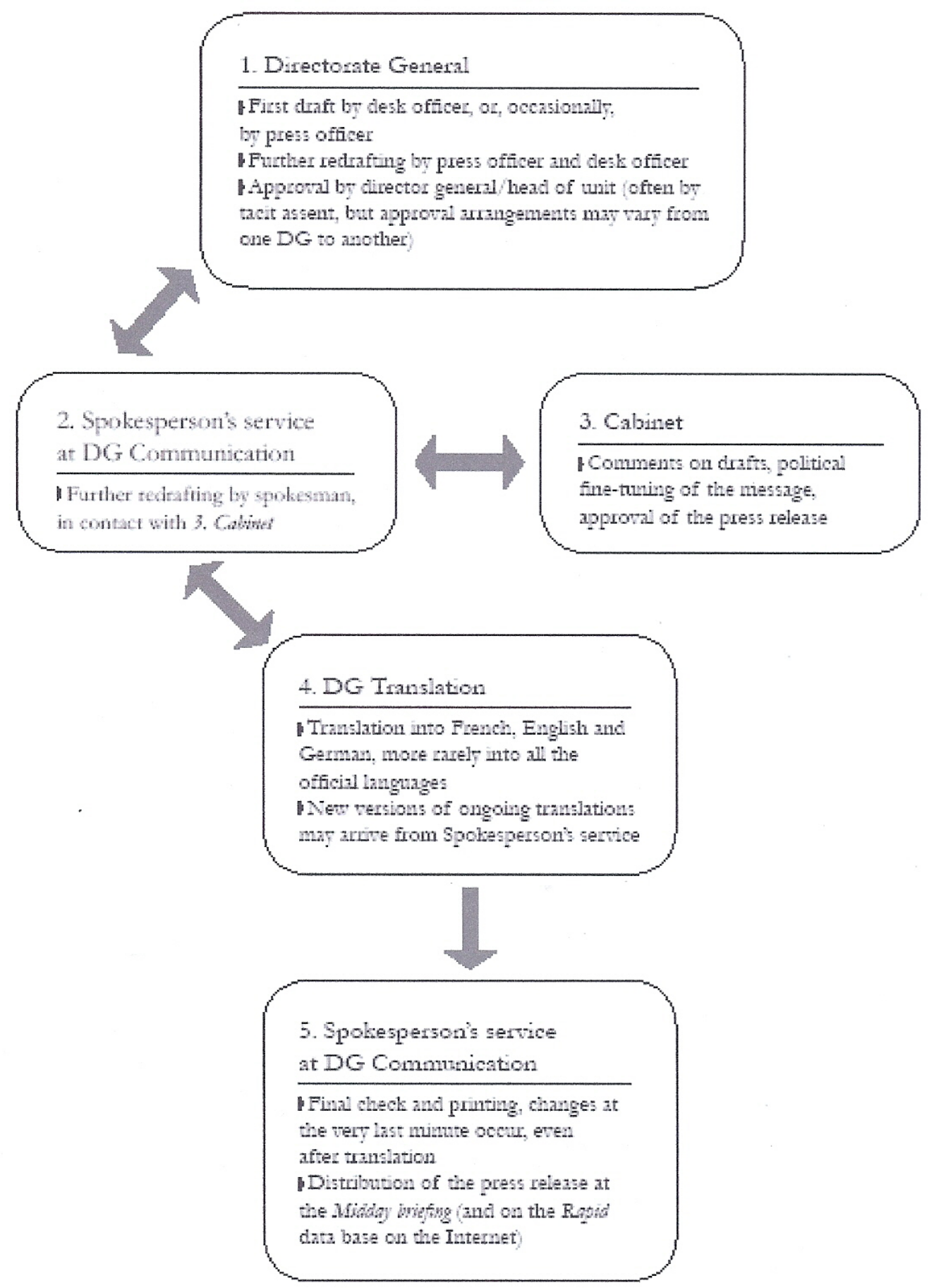

Figure 1 - The genesis of a typical Commission press release

${ }^{20}$ Telephone conversation at the Commission in February 2005. 


\section{The Directorate-General}

The first draft of a press release is made at the DG of the given policy area. Most press releases are now drafted in English, but this can vary for different reasons. The initiative may come from the DG, the spokesperson or the cabinet, most often from the DG. The draft is usually written by the person in the unit responsible for the dossier. He or she may very well be a non-native speaker, just like any others involved in the genesis of a press release. Ideally, however, at least one native speaker should have read the press release before it is issued. Occasionally, drafts are also produced by the press officer from material supplied by the unit.

The first draft can be very technical, since the person who has been working, for instance, on a directive or a regulation on road safety, may be asked to write the draft press release without necessarily any prior communication training or understanding of the requirements of the genre. For instance, an official who was to write a first draft and asked for a model was directed to the Rapid data base, the Commission database on the Europa portal site, containing not only Commission press releases, Memos ${ }^{21}$ and commissioners' speeches, but news from other EU institutions. The explicit guidelines given by the press officer emphasised that the most important task was to put the political message of the Commission across. The official was advised to write as concisely as possible, and to include an introduction which would summarize the essentials of the message. If the journalist wanted further information than given by the press release, it would be provided for in the accompanying Memo. As for the format, the maximal length was set at 3000 characters, Arial 11 for the body of the text and Arial 16 for the title. However, the official did not have to be too preoccupied with the form, since that is the press officer's task ${ }^{22}$.

Many Directorates-General nowadays have a press officer in their information unit, a person in charge of "mediatising" the press release before sending it on to the spokesperson at the DG Communication. In that sense, the press officer at, say, the DG Agriculture is the link between the DG and the spokesperson, who is then the link with the commissioner and the journalists.

Several versions are elaborated in the DG before the press officer sends the press release to the spokesperson at the DG Communication. Quite frequently, more than one DG is involved in the production process. In this case, one DG is responsible and the other one is consulted. For instance, press releases may have quotations from more than one commissioner, which indicates that they are relevant to more than one policy area.

\section{2. and 3. Spokesperson's service at the DG Communication and the Cabinet}

If the spokesperson feels this is necessary, he or she continues working on the text, in close contact with the cabinet, i.e. the commissioner's staff. The commissioner in person rarely gets involved in the drafting of a press release, whereas heads of cabinet show an increased interest in the press releases. The text may go back and forth between DG, spokesperson and cabinet. To complicate the matter further, the people involved in the drafting, for instance the spokesperson and the cabinet, can also work simultaneously on different versions of the same press release "to save time".

21 A Memo is sometimes issued together with a press release in order to explain the more technical background (often in the format of questions and answers).

22 E-mail exchange with a press officer in April 2005. 


\section{DG Translation}

When the spokesperson decides that the text is ready for issuing or when the time limit has it that way, it is sent to DG Translation for translation and issued at the Midday briefing. However, DG Translation may receive new versions of ongoing translations from Spokesperson's service. The press release should always exist in three language versions at least: English, French and German. However, it rarely exists in German at the time of the Midday briefing, and it is not uncommon that the English version is the only one available at the press conference. This is frequently criticized by the journalists, but is not necessarily due to delays at DG Translation.

\section{Spokesperson's service at DG Communication}

The spokesperson receives the translated versions from DG Translation and gives green light for issuing the press release. Thereafter the press release is printed and distributed at the Midday briefing. Changes in the press release occur at the very last minute, even after translation, and this is a highly informal procedure.

A few hours after the Midday briefing, the press release is made available on Rapid. Other language versions may be put on Rapid in the following days, which indicates that the receivers are a wider group than first expected, i.e. other journalists than the Brussels based ones as well as the general public.

To sum up, the production of a press release is obviously far from a linear process. More people than those mentioned can be involved ranging from heads of cabinet to secretaries at the DGs and at DG Communication, and the approval arrangements vary from one DG to another. To further complicate the matter, divergent opinions about how the press release should be written were made explicit by Commission officials. In the next section, I will return to the introduction, the quotation and the intertextual references to see to what extent the ethnographic material provided in this section can shed light on them. I will also touch upon the issue of the length again. What is at stake here is to see if the length restriction of May 2004 had any impact on the three central text features discussed in this paper.

\section{The Commission press release text pattern - second round of analysis}

The first of the characteristic textual features I put forward was the introduction. This could be related to the fact that the Commission press releases are longer than the national ones. Yet, the length of the text is not the most important reason. Commission press releases have to start with an introduction because it is used as a summary in the Midday Express which is issued every day in connection with the Midday briefing. The Midday Express can be subscribed to electronically and it contains the introductions of all the press releases of a given day as well as references to other material issued, for instance commissioners' speeches. At several points, I have already touched upon the role of the Midday Express in the distribution of the Commission news. Many people involved in the text production are aware of the fact that journalists may only read the introduction, which explains why it should be able to stand alone as a summary in the Midday Express. Hence it is not possible to skip this introduction in favour of a punchier or catchier way of presenting the news. Accordingly, the introduction has to summarise the whole press release to "close the circle", instead of simply forming the 
first paragraph of a text ${ }^{23}$. In this respect, a summarising function can be assigned to the introduction of the Commission press release: It is not only there to introduce but to give the essentials of the press release in a condensed form. The Midday Express was introduced in 1995, and the year after the introduction became an obligatory feature of the press release.

Next, I will address the systematic presence of a quotation in the Commission press release. This is the part where the Commission can allow itself to put a political message forward. The quotation leaves the floor open to the commissioner who can more easily be argumentative than the Commission as an institution, at least if the press release is to be taken as news and not as a special plea by the Commission. Incidentally, those who write a press release for the first time are instructed to focus on the political message of the Commission, which reveals an underlying political purpose, in addition to an informative one (cf. example 6 above). Indeed, the Commission is highly aware of the potential of the quotation as a spin for the Commission message:

Remember that the quote is very important since it is the only part of the press release that a journalist cannot change or rewrite. The quote should be short and memorable. Read your quote aloud. If it does not sound like ordinary human speech, it is not a good quote (European Commission 2003: 3).

The quotation is often already put in the first drafts, but may be subject to substantial changes during the rest of the writing process. Most quotes are completely made up (on this issue, see also Bastin 2005). According to an official at the French representation's press service in Brussels, the quotations are not as crucial in France as they are to the Commission: The relevant minister can comment on issues more easily in France than can the commissioner in the 27 different member states. Therefore, the press release may be seen as second-hand information. Following this reasoning, the press release would be less important from a political point of view in France, a view that was confirmed in some of my telephone interviews with press officers at French ministries.

Finally, as far as the intertextual references are concerned, they are less frequent in the national press releases. I have suggested throughout this paper that the communication situation of the Commission is more complex than that of the national ministries, and to explain the higher degree of intertextuality in the Commission press release, one would have to situate the Commission text in the broader EU context. First of all, the decision procedure is extremely complicated. The Commission cannot always decide on what will happen with an initiative. The Commission proposes, but the Parliament and the Council decide. Therefore, the Commission constantly seeks to legitimise its actions, and to justify why a particular initiative has been taken or should be approved by the other institutions. One way of doing so is to contextualise the press release with references to other initiatives or programmes. In a previous example (number 7), we have seen that a communication on "Providing new momentum for the European Research Area” was mentioned by name. The same excerpt also showed how the communication is a part of the "European Research Area initiative", which was launched at the "Lisbon European Council in March 2000". Furthermore, the "Sixth

23 One of my case studies of the genesis of a press release (Lindholm 2007) reveals that a final sentence to summarise the end of the press release was added to the introduction during the production process, precisely so that the introduction could "stand alone as a summary of the key points" (European Commission 2003: 2). 
European Framework Programme for Research" has been created to implement the initiative, and "structures for contacts between private and public research players have been set up at European level in several areas”, the press release says (IP/02/1488). The need for legitimisation by referring to a larger context of action also appears from the following extract:

The usefulness of intermediaries has been confirmed by existing experience in the on-line collection of feedback, namely the Business Feedback Mechanism (BFM), launched by the Commission in April 2000 as part of the 'Dialogue with Business' (see IP/00/391) (IP/01/519, my emphasis).

On the whole, the EU political context is quite intricate compared with the national one, with high complexity of the issues on the agenda, which brings about an explanatory need. One initiative is part of another in a chain of events (see example 8 above, which refers to another press release (IP/00/391))) and may require additional technical explanations. This is where the Memo comes in. Perhaps more than the two other textual features examined, the intertextual references serve a legitimising purpose; since the EU is still a "work in progress", the actions of the Commission are likely to need more back-up than those of a national ministry.

Before concluding, I will return to the issue of length. At the outset of this paper, I indicated that the Commission press releases are shorter now than when I collected my corpus. I believe that this kind of genre change is functional rather than arbitrary (Kankaanpää 2001) and one explanation of this change has already been put forward. In fact, at the moment of the enlargement with ten new member states in May 2004, DG Translation set a maximum length for a number of different types of texts, due to lack of translation capacity. Accordingly, a press release must not exceed 3000 characters (not including spaces) (European Commission 2004) ${ }^{24}$. All the people with whom I have discussed this issue believe it is a change for the better, but it is noteworthy that the change was due to "external reasons" imposed on the DG Communication and not an internal decision at the service to shorten the texts.

In order to see what kind of macro-textual changes, if any, this new order has brought about, the French language versions of 101 Commission press releases from February 2005 have been examined at the level of meta-structure. Indeed, the average length was reduced from 1060 words to 554 words. Interestingly, the textual features identified in this paper are still present to the same degree. All press releases contained an introduction, 85 contained at least one quotation (84\%) and 50 of the 101 press releases $(50 \%)$ contained intertextual references ${ }^{25}$. Although the consequences of the length restriction need to be examined in more detail, it is worth noting that the three features remain and that this is a good indicator of their crucial importance for the Commission press release.

Following this line of argument, I think it is reasonable to talk about a Commission text pattern where a higher degree of quotations and intertextual references as well as a

24 These new restrictions have been modified in 2005 (European Commission 2005a) resulting in more flexible length limits; the translation capacity has augmented as recruitment of translators for the new languages is advancing. For the press releases, the new maximum length is of 4500 characters.

25 The corresponding figures for the original corpus were $80 \%$ quotations and $56 \%$ of intertextual references, and an introduction in every press release. 
mandatory introduction should be seen as crucial features ${ }^{26}$. It was put forward earlier in the paper that it would be interesting to examine whether the institutional EU setting would lead to the development of a unique text pattern. I have shown that the specific conditions of the context in which the press releases of the Commission function apparently lead to a text pattern which is different from those of two equivalent groups of national texts.

\section{Concluding remarks}

Recapitulating this study, I proposed, at the outset, to study the European Commission press release in the light of the complex and collective nature of the text production and the overall communicative situation. I proposed a model for a structural analysis of the genre taking into account the level of internal structure, the situated level and the level of external structure. They correspond in turn to the features of the press release examined, the immediate production and distribution context and the wider aspects of the communicative situation of the Commission. Based on the fieldwork experience, I would argue that the method chosen gives a fuller account of the press release than a purely text based approach. Inversely, the ethnographic data provided becomes particularly relevant when applied to concrete textual artefacts, instead of being used for background information only.

As for the first feature, the introduction, it draws primarily, and most evidently, on the situative level. The mandatory introduction in the Commission press release is not essentially a result of the fact that the Commission press releases are much longer than the national press releases. Instead, the introduction should be able to stand alone as a summary in the daily Midday Express issued by the Commission together with the press releases at the daily press conference in Brussels.

The motivation for the quotation, the second text feature analysed, is twofold. First, the Commission as sender is somewhat diffuse and an identifiable person renders a human face to the Commission. This need seems to be common to the genre: The national press releases also had an individual person, the minister, present in most of the texts (although not in quoted form in the French press releases). Secondly, the genre expectations of a press release imply that it must not be an arena for political debate. Instead, the quotation allows for persuasion instead of just information, since the commissioner and not the whole Commission is responsible for the utterance. The persuasive dimension is perhaps even more important to the Commission than to the national ministries, since the press release clearly serves a legitimising purpose in addition to the informative one. The Commission is not in the same indisputable situation as a national ministry to engage in various actions. The quotation provides clear textual evidence for this. On the whole, the quotation should be interpreted as less important at the situative level, since, interestingly, the journalists enter into direct contact with the Commission at the Midday briefing and can ask the relevant

26 The "community text pattern" of the title of this paper refers to the popular idea of a "Community language", a concept that is to a large extent absent in academic discourse. This study only covers one aspect of linguistic use, on a macro-structural level, and only one institution, which makes it presumptuous to talk about a community text pattern. On the other hand, the results of this study clearly point to a Commission text pattern of the press releases. It would be interesting to study the press releases of all the EU institutions in this respect. 
spokesperson for further comments. Nevertheless, striving for press coverage, the Commission is conscious of the fact that a quotation may serve the journalists in the subsequent news reporting; indeed quotations are, in general terms, frequent in press releases.

As far as intertextuality is concerned, it is a textual strategy more frequently exploited by the Commission. It was argued that the explicit intertextual references can be an indicator of the more complex communicative situation of the Commission since the Commission - in need of legitimising its actions - depends on other texts or initiatives to motivate its activities. Many of the Commission's actions are in fact part of an ongoing process. Consequently, intertextuality concerns both the situative level and the level of external structure, since several of the texts drawn upon are issued together with the press release at the Midday briefing, and the need to provide more background information appears to be provoked by the overall communicative situation.

Clearly, the Commission press release serves several purposes, not only the one of informing the Brussels based correspondents about its initiatives. We have identified a persuasive aim: The Commission needs to convince the reader that actions on the EU level are necessary. Also, the Commission is legitimising its own actions by referring to an ongoing process of initiatives. The fact that the Commission press release serves several purposes (some being different from those of national ministries) does not mean that the groups of texts studied here cannot all be given the same generic label of press release. They are all a means to address journalists (and citizens) and share, so to speak, a similar framing. On the other hand, they display differences and are institutionally specific. As for the Commission, an interesting aspect to take into more careful consideration in later studies is how the different cultural backgrounds of the people involved in the drafting of press releases affect the final text.

The wider research project which this paper is part of (Lindholm 2007), however indicates that the main features of the Commission press release production come close to those of a national ministry, which implies that detailed studies of the text production of the European Commission not only shed light on a particular institution but on press release production more generally, for instance in government organisations. It can therefore be argued that this research opens up for further studies of press release production of other national and international organisations.

\section{Acknowledgments}

I am grateful for comments on earlier drafts on this paper generously provided by Geert Jacobs, Henk Pander Maat, Charles Briggs and two anonymous reviewers.

\section{References}

Abélès, Marc (1996) En attente d'Europe. Paris: Hachette.

Amossy, Ruth (ed.) (1999) Images de soi dans le discours : La construction de l'ethos. Lausanne: Delachaux et Niestlé. 
Askehave, Inger (1999) Communicative purpose as genre determinant. Hermes, Journal of Linguistics 23 : 13-23.

Askehave, Inger, John M. Swales (2001) Genre identification and communicative purpose: A problem and a possible solution. Applied Linguistics 22.2: 195-212.

Bakhtin, Mikhail M. (1986) The problem of speech genres. In C. Emerson \& M. Holquist (eds.), Speech genres and other late essays. Austin: University of Texas Press, pp. 60-102.

Baisnée, Olivier (2000) Les journalistes, seul public de l’Union européenne? Critique internationale 9: 30-35.

Baisnée, Olivier (2003) La production de l'actualité communautaire. Éléments d'une sociologie comparée du corps de presse de l'Union européenne. Ph.D. thesis. Rennes: Université de Rennes I-IEP de Rennes.

Baisnée, Olivier (2004) The politics of the Commission as an information source. In A. Smith (ed.), Politics and the European Commission: Actors, interdependance, legitimacy. London: Routledge, pp. 134-155.

Balboni, Paolo E. (2004) Being many and being one: The language policy of the European Union. Mosaic 8.3: 3-9.

Bastin, Gilles (2003) Les professionnels de l'information européenne à Bruxelles: Sociologie d'un monde d'information (territoires, carrières, dispositifs). Ph.D. thesis. Bruxelles: École Normale Supérieure de Cachan.

Bastin, Gilles (2005) Comment les mots viennent à Margot Wallström. Problèmes d'intermédiation de l'action publique européenne à Bruxelles dans les années 2000. In D. Filâtre \& G. de Terssac (eds.), Les dynamiques intermédiaires au cœur de l'action publique. Toulouse: Octares Éditions, pp. 213-223.

Bellier, Irène (2002) European identity, institutions and languages in the context of enlargement. Journal of Language and Politics 1.1: 85-114.

Berteloot, Pascale (2002) Legal French in France and in the European Communities. In H.E.S. Mattila. (ed.), The Development of Legal Language. Helsinki: Kauppakaari, pp. 81-99.

Connor, Ulla, and Anna Mauranen (1999) Linguistic analysis of grant proposals: European Union research grants. English for Specific Purposes 18.1: 47-62.

Dacheux, Éric (2004) Lé déficit de communication de l’Union européenne : Cause ou symptôme de la crise de légitimité des institutions? In É. Dacheux. (ed.), L'Europe qui se construit : Réflexions sur l'espace public européen. Saint-Étienne: Publications de l’Université de Saint-Étienne, pp. 83-108.

Diez, Thomas (1999) Speaking 'Europe': The politics of integration discourse. Journal of European Public Policy 6.4: 598-613.

Duchêne, Alexandre (2004) Construction institutionnelle des discours : Idéologies et pratiques dans une organisation supranationale. Travaux neuchâtelois de linguistique 40: 93-115.

Duchêne, Alexandre (2006) "Dans les Etats où il existe des minorités ..." : Les conditions de production institutionnelle, discursivité et idéologique d'un article de loi aux Nations Unies. Semen - Revue de sémio-linguistique des textes et discours 21: 121-140. 
European Commission (1993) Reflection on Information and Communication Policy of the European Commission. Brussels: European Commission.

European Commission (2001) A new framework for co-operation on activities concerning the information and communication policy of the European Union, COM(2001) 354 final. Brussels: European Commission.

European Commission (2003) Style guide for press releases. Brussels: DG Press and Communication, European Commission.

European Commission (2004) Matching supply and demand for translation, SEC(2004) 638. Brussels: European Commission.

European Commission (2005a) Translation in a multilingual community, SEC(2005) 984/3. Brussels: European Commission.

European Commission (2005b) Simplifying EU legislation makes life easier for citizens and enterprises, MEMO/05/394. Brussels: European Commission.

European Commission (2006) White paper on a European Communication Policy, COM (2006) 35 final. Brussels: European Commission.

Fairclough, Norman (1992) Discourse and social change. Cambridge: Polity.

Foret, François (2004) Advertising Europe. In A. Smith (ed.), Politics and the European Commission: Actors, interdependence, legitimacy. London: Routledge, pp. 156-169.

Genette, Gerard (1992) The architext: An introduction. Berkeley: University of California Press.

Goffin, Roger (1997) L'Eurolecte: Le langage d'une Europe communautaire en devenir. Terminologie et traduction 1: 63-74.

Guiraudon, Virginie (ed.) (2000) Sociologie de l'Europe. Mobilisations, élites et configurations institutionnelles. Cultures et Conflits n ${ }^{0} 38-39$.

Gunnarsson, Britt-Louise (1996) Den europeiska skrivgemenskapen - finns den? Om textmönster i kontrastiv belysning. In G. Gren-Eklund. (ed.), Att förstå Europa - mångfald och sammanhang: Humanistdagarna vid Uppsala universitet 1994. Uppsala: Uppsala universitet, pp. 225-238.

Günthner, Susanne, and Hubert Knoblauc (1995) Culturally patterned speaking practices - the analysis of communicative genres. Pragmatics 5.1: 1-32.

Jacobs, Geert (1999) Preformulating the news: An analysis of the metapragmatics of press releases. Amsterdam: John Benjamins Publishing Company.

Joana, Joana, and Andy Smith (2002) Les commissaires européens: Technocrates, diplomates ou politiques? Paris: Presses de Sciences Po. 


\section{Maria Lindholm}

Kankaanpää, Salli (2001) From letters to news reports: Diachronic changes in Finnish municipal press releases 1979-1999. In W. Vagle \& K. Wikberg. (eds.), New directions in nordic text linguistics and discourse analysis: Methodological issues. Oslo: Novus forlag, pp. 229-242.

Koskinen, Kaisa (2000) Institutional illusions. Translating in the European Commission. The Translator 6.1: 49-65.

Lassen, Inger (2006) Is the press release a genre? A study of form and content. Discourse Studies 8.4: 503-530.

Lequesne, Christian, and Andy Smith (eds.) (1997) Interpréter l’Europe. Cultures et Conflits n 28.

Lindholm, Maria (2007) La Commission européenne et ses pratiques communicatives. Étude des dimensions linguistiques et des enjeux politiques des communiqués de presse. Ph.D. thesis. Linköping: Department of Culture and Communication.

Lodge, Juliet (1994) Transparency and democratic legitimacy. Journal of Common Market Studies 32.3: 343-368.

Loos, Eugène (2004) Composing "panacea” texts at the European Parliament. An intertextual perspective on text production in a multilingual community. Journal of Language and Politics 3.1: 3-25.

Luckmann, Thomas (1989) Prolegomena to a social theory of communicative genres. Slovene studies: Journal of the Society for Slovene Studies 11.1-2: 159-166.

Maingueneau, Dominique (2002) Les rapports des organisations internationales: Un discours constituant ? Nouveaux Cahiers de l'IUED 13: 119-132.

Mamadouh, Virginie (1999) Beyond nationalism: Three visions of the European Union and their implications for the linguistic regime of its institutions. GeoJournal 48: 133-144.

Marzocchi, Carlo (2005) On a contradiction in the discourse on language arrangements in the EU institutions. Across Languages and Cultures 6.1: 5-12.

Mauranen, Anna (1993) Cultural differences in academic rhetoric: A textlinguistic study. Frankfurt am Main: Lang.

Meyer, Christoph (1999) Political legitimacy and the invisibility of politics: Exploring the European Union’s communication deficit. Journal of Common Market Studies 37.4: 617-39.

Muntigl, Peter, Weiss, Gilbert, Wodak, Ruth (eds.) (2000) European Union discourses on un/employment: An interdisciplinary approach to employment policy-making and organizational change. Amsterdam/Philadelphia: John Benjamins Publishing Company.

Schlesinger, Philip (1999) Changing spaces of political communication: The Case of the European Union. Political Communication 16.3: 263-279.

Schlesinger, Philip (2003) The Babel of Europe? An essay on networks and communicative spaces. Oslo: Arena Working Papers 22/03: 1-26.

Schäffner, Christina (ed.) (2001) Language work and the European Union, special issue. Perspectives: Studies in Translatology 9: 4. 
Shore, Cris, and Marc Abélès (2004) Debating the European Union. An interview with Cris Shore and Marc Abélès. Anthropology Today 20.2: 14.

Smith, Andy (1999) L’'espace public européen': Une vue (trop) aérienne. Critique internationale 2: 169-180.

Smith, Andy (2000) Institutions et intégration européenne. Une méthode de recherche pour un objet problématisé. In M. Bachir (ed.), CURAPP, Les méthodes au concret. Démarches, formes de l'expérience et terrain d'investigation en science politique. Paris: PUF, pp. 229-252.

Sosonis, Vilelmini (2005) Multilingualism in Europe: Blessing or curse? In A. Branchadell (ed.), Less translated languages. Philadelphia, PA: John Benjamins Publishing Company, pp. 39-47.

Tardy, Christine M. (2003) A genre system view of the funding of academic research. Written Communication 20.1: 7-36.

Vergaro, Carla (2005) 'Dear Sirs, I hope you will find this information useful': Discourse strategies in Italian and English ‘For Your Information’ (FYI) letters. Discourse Studies 7.1: 109-135.

Wodak, Ruth (2000) From conflict to consensus? The co-construction of a policy paper. In P. Muntigl, G. Weiss \& R. Wodak (eds.), European Union discourses on un/employment: An interdisciplinary approach to employment policy-making and organizational change. Amsterdam/Philadelphia: John Benjamins Publishing Company, pp. 73-114.

Appendix A - A European Commission press release

IP/02/1488

Brussels, 16 October 2002

The European Research Area: The Member States must do more, says the Commission

Philippe Busquin, the European Research Commissioner today put forward suggestions for promoting the European Research Area initiative. The communication entitled "Providing new momentum for the European Research Area" suggests that the mechanisms for coordinating national research policies should be strengthened and made more efficient. To this end, it proposes that common objectives should be determined and translated into specific objectives for each country and that annual national reports should be drawn up. This mechanism would be implemented by high-level representatives of the Member States. Greater use should also be made of legal measures, for example concerning the mobility of researchers. Launched at the Lisbon European Council in March 2000, the European Research Area initiative has become the reference framework for research policy in Europe. Its objective is both to create a genuine "internal market" in research and knowledge, and improve the coordination of national research activities and policies. 
Philippe Busquin, the European Research Commissioner, said: "Thirty months after it was launched, the European Research Area initiative can be said to have reshaped the European Research policy landscape. The national research organisations are starting to define their activities in relation to it, and it has given rise to concrete achievements. However, the initiative is suffering from the fact that the Member States are still showing insufficient commitment. The involvement of the national administrations in the various activities needs to be stimulated, and mechanisms should be put in place to help improve the coordination of national research policies".

\section{Making a reality of the European Research Area}

The European Research Area is an important component in achieving the objective of making the EU the world's most competitive and dynamic knowledge-based economy. Apart from the low level of its overall spending on research $1.9 \%$ of the EU's GDP compared with $2.7 \%$ for the USA and $3 \%$ for Japan), and the fact that it is less able to exploit the results of scientific work in economic terms, Europe's main weakness in the field of research is the fragmentation and dispersion of its activities.

To overcome this weakness, all the research activities carried out in Europe, some $80 \%$ of which are funded and carried out at national level, should be conducted within a common reference framework. And the national and regional research policies should be implemented in a more coherent and coordinated fashion.

\section{Some progress and some success, but within limits}

The European Research Area initiative has already resulted in achievements such as the first results of an exercise to benchmark the performance of the national research policies on the basis of twenty indicators, and the development of a European network of researcher mobility and assistance centres which will be launched at the beginning of 2003.

The Sixth European Framework Programme for Research (2003-2006) was specifically designed to help bring about a European Research Area, by means, in particular, of new instruments such as the networks of excellence and integrated projects, stepping up action in the fields of infrastructures and mobility, and a scheme to support initiatives for the networking of national activities.

Structures for contacts between private and public research players have been set up at European level in several areas (ACARE for aeronautical research; ERRAC for railway research), and initiatives to coordinate national research activities have been launched, for example research into TSEs (Transmissible Spongiform Encephalopathies).

However, the European Research Area initiative suffers from the fact that the national research policies are insufficiently coordinated.

\section{New perspectives}

To overcome this limitation, the Commission is proposing:

- To define a formal coordination mechanism which could be based on the system of annual national reports as used in the fields of economic and employment policies; 
- To establish a structure capable of ensuring this coordination, in which the national administrations will be represented at the highest level;

- To make use of the full open coordination method without cutting out the first two stages: setting common objectives and translating them into specific targets for each country.

In addition, a special effort should be made to help the candidate countries to integrate themselves into the European Research Area. The Commission also proposes to step up ongoing activities, for example by putting forward measures designed to help third country researchers to come to and stay in Europe, and recommendations concerning career development for researchers.

Implementing these new perspectives for the European Research Area would complement the action undertaken to increase overall European spending on research to 3\% of GDP by 2010.

Further information is available on the following website:

http://europa.eu.int/comm/research/era/index_en.html

\section{Appendix B -}

Extract from the Midday Express of 16 October $2002^{27}$

Midday Express of 2002-10-16

Reference: MEX/02/1016 Date: 16/10/2002

HTML:

$\underline{\mathrm{EN}}$

PDF:

DOC:

\section{Résultats de la Commission de ce jour - Outcome of today's Commission meeting}

- Commission considers that an excessive government deficit exists in Portugal

The European Commission, in an opinion on the budgetary situation

27 The Midday Express nowadays puts “News from the Press and Communication Directorate General's midday briefing” and "Nouvelles du rendez-vous de midi de la Direction Générale Presse et Communication” just after the title Midday Express. The extract shown in the Appendix gives the introduction of the IP/02/1488 in French, since it was originally drafted in French. It could be interesting to compare it to the English language version in Appendix A. When made available in Rapid, the contact information (to the relevant spokesperson) gives at the end of each introduction, and at the end of each press release, is left out. 
prepared under the obligations of Article 104.5 of the Treaty and adopted today, concludes that an excessive deficit exists in Portugal. On the basis of Article 104.6, it recommends to the Council to adopt a similar decision. Finally, the Commission recommends to the Council to address a recommendation to Portugal, in the sense of Article 104.7. The Portuguese government should adopt and implement all necessary measures in order to ensure that the general government deficit is reduced to clearly below 3\% of GDP in 2003 and that the government debt ratio is kept below 60\% of the GDP reference value. Necessary measures have to be adopted at the latest by 5 March 2003. With today's decision the Commission is honouring its obligations laid down in Article 104 of the Treaty, as well as its political commitments given in the European Council resolution on the Stability and Growth Pact for a strict, timely and effective functioning of the Pact.

- Espace européen de la recherche : les Etats membres doivent faire plus, dit la Commission

Le Commissaire européen chargé de la Recherche Philippe Busquin a présenté aujourd'hui des suggestions pour promouvoir le projet d'Espace européen de la recherche. La Communication "L'Espace européen de la recherche: un nouvel élan" suggère de renforcer et de rendre plus performants les mécanismes de coordination des politiques de recherche nationales. Elle propose, pour ce faire, de déterminer des objectifs communs, de les traduire en objectifs particuliers pour chaque pays, et d'établir des rapports nationaux annuels. Ce mécanisme serait mis en œuvre par des représentants de haut niveau des Etats membres. Il s'agirait aussi de recourir davantage aux mesures légales, par exemple en matière de mobilité des chercheurs. Lancé au Conseil européen de Lisbonne de mars 2000, le projet d'Espace européen de la recherche est devenu le cadre de référence pour la politique de recherche en Europe. Son objectif est à la fois de créer un véritable "marché intérieur" de la recherche et de la connaissance, et d'améliorer la coordination des activités et des politiques nationales de recherche. 